\title{
Rol de los sistemas de producción de aves y cerdos de traspatio en la emergencia y mantención de patógenos zoonóticos en Chile
}

\author{
Christopher Hamilton- West, F. Di Pillo, S. Ruiz, D. Rivera, E. Gómez, D Jiménez. \\ Departamento de Medicina Preventiva Animal, Facultad de Ciencias Veterinarias y Pecuarias, Universidad \\ de Chile. Santa Rosa 11.735, La Pintana. Casilla 2, correo 15, La Granja. Email: \\ christopher.hamilton@veterinaria.uchile.cl
}

\begin{abstract}
Resumen
En Chile la producción de aves y cerdos se concentra en unidades de producción industrial con altos estándares de productividad, calidad y bioseguridad. Este sector industrial concentra más del $85 \%$ de las poblaciones de aves y cerdos en el país.

Sin embargo, existen otras formas de producción animal. Una de ellas está en manos de pequeños productores, y se denomina como "producción animal de traspatio", que en Chile estaría representada por más de 150 mil productores, 3,7 millones de aves y 400 mil cerdos.

Los sistemas de producción animal de traspatio (SPT) son considerados como la forma de producción animal más común a nivel mundial. Además, se reconoce que la mantención de estas unidades productivas juega un rol relevante para subsistencia de pequeños agricultores y su grupo familiar, siendo principalmente un complemento a las fuentes de alimentación que generan recursos económicos esporádicos. Sin embargo, se generaliza a estas unidades productivas como poseedoras de severas deficiencias en bioseguridad.
\end{abstract}

Existen diversos factores que participan en la emergencia, re-emergencia y mantención de patógenos zoonóticos. Entre estos se destaca el contacto entre especies de animales domésticos, especies de animales silvestres y el hombre. Esta situación se presentaría comúnmente en los SPT. Esta investigación tiene por objetivo caracterizar la forma de producción en SPT que mantienen aves y cerdos en la zona central de Chile, identificando factores de riesgo para la (re)-emergencia y mantención de patógenos zoonóticos prioritarios como son virus de influenza A, y cepas de Salmonella, E. Coli y Campylobacter, y además, recoger evidencias de la circulación de estos patógenos en los SPT.

Agradecimientos:

- Programa U-INICIA Concurso de Reforzamiento de Inserción Productiva de Nuevos Académicos VID 2011; U-INICIA 11/12

- $\quad$ Proyecto FONDECYT 11121389 